\title{
POSSIBILITIES TO PREVENT NEGATIVE ENVIRONMENTAL IMPACTS
}

\author{
Igor Trišić ${ }^{1}$, Snežana Štetić2 ${ }^{2}$ Vesna Krstic $c^{3}$ \\ *Corresponding authorE-mail: trisici@hotmail.com
}

\begin{abstract}
A R T I C LE IN F O
A B S T R A C T

Review Article

Received:30 August 2018

Accepted: 04 December 2018

doi:10.5937/ekoPolj1804599T

UDC 338.484:502.131.1

This research paper introduces results of research through analyses of a significant number of activities, aimed at preventing the negative impact of tourism in the area of its operating, observed through a selected number of exemplified managing system protections, in particular world's natural sites, including the Republic of Serbia. Important models of protection are presented through

Keywords:

Tourism, nature protection, sustainable tourism development.

JEL: Z32, Q57 numerous case studies, among which, especially observed, and noted in this research paper are: establishing site protection status on an international and local level, zoning of tourism and site carrying capacity. Taken into consideration, these models can give positive results by contributing the planning strategies of other countries or regions, including the Republic of Serbia. With regular monitoring, they are to bring constitution to novel or implement the existing measures of protection, aimed at promoting positive ecological and social long-term outcomes.
\end{abstract}

(C) 2018 EA. All rights reserved.

\section{Introduction}

Tourism development has an impact on creating different positive and negative environmental effects. Tourism brings foreign exchange flow that strengthens economic development and improves national economy. However, tourism also brings all those negative consequences, that can affect sustainable local community growth, unless its development is being taken care of. In this way, the tourism can develop significant consequences, some being devastating for surroundings and the environment it is

1 Igor Trišić, PhD student, University of Kragujevac, Faculty of Hotel Management and Tourism, Vojvođanska №5a, 36210 Vrnjačka Banja; Republic of Serbia, Phone: +381641431375, E-mail: trisici@hotmail.com, ORCID ID (https://orcid.org/0000-0002-6497-9276)

2 Snežana Štetić, PhD, Full Professor, The College of Tourism Belgrade, Bulevar Zorana Đinđića №152a, 11070 Belgrade, Republic of Serbia, Phone: +38163239853, E-mail: snegics@gmail.com, ORCID ID (https://orcid.org/0000-0002-1137-4441)

3 Vesna Krstić, PhD student, University of Kragujevac, Faculty of Hotel Management and Tourism, Vojvođanska №5a, 36210 Vrnjačka Banja; Republic of Serbia, Phone: +38162552893, E-mail: vesnak16@hotmail.com, ORCID ID (https://orcid.org/0000-0003-2541-5440) 
operating in. The cause of this are uncontrolled negative effects on the elements of natural living environment, such as air, water, soil, flora and fauna. Many countries' concern today is constant preventing of the bad influences, as well as the support of good ones. By implementing positive actions and measures, these bad influences can be eliminated or brought to a minimum. Along important measures of protection and possible models for preventing bad influences, this research paper documents the following: adopting and establishing measures and forms of protection, zoning, within which the tourist movements are made, and carrying capacity as a recommended form of maximzied number of site visitors at a certain time interval. Data analysis examples from the worldwide pratice can in many ways serve either the existing or the future models of prevention. The object of the study are different site protection status, zoning and carrying capacities.

\section{Methodology}

In this research a method of content analysis for written information will be used. This method objectively describes the content and importance of information, thus eliminating a possibilty of incomplete assessment of the indicated matter. For the purpose of this research, various data sources have been used from the field of tourism and natural environment protection, based on data related to preventing the impacts of tourism on the environment, through selected methods. Quantitative and qualitative content analysis of different data and analyzing will be applied. Accordingly, the base method relates to adopting and passing of legal acts by different subjects in protection procedures, implementing of these regulations, establishing protection zones and site carrying capacity. The collected written data has been analyzed and presented, with final aim at giving conclusions and judgements about the existing models and states for environmental protection in tourism.

\section{Results and discussion}

Numerous international analysis results indicate that one half of global tourist movements belong to geotourism, i.e., travelling to certain geographical destinations, mostly attractions within protected natural environment. Globalization of tourism and its spreading has contributed to creating numerous studies and projections which, based on experience, analyze the relationship of tourism towards environmental resources. Tightly connected with these projections is the idea of sustainable tourism, as a way of optimal use of tourist resources, without degradation, along possiblity of being applied by future generations (Stojanović, Stamenković, 2008). Sustainable tourism development in a certain site should explain how to preserve this site and tourist development at the same time, i.e., how to prevent tourist, ecological and sociocultural devastation of the given site (Štetić et al., 2013). Agriculture, as an important economic activity, also takes special place in sustainable development because it is a significant pollutant in nature. On the other hand, it is tightly connected with tourism because it represents the main provider of tourism industry. In the last few decades, especially in developed countries, economic, 
ecological and social development are balanced, with multifunctional agriculture taking special place (Delić et al., 2017). In order to explore the site as a 'framework' and offer guidelines for qualitative 'stage' for creating and developing tourism product, we have to consider basic settings and changes in tourist flows on a global level, in order to have an impact on: following changes in diversification of global tourist movements, changes within tourist offer and dramatic price decreases of 'basic tourist product', increased need for visiting preserved natural environment and keeping balance between mass and sustainable tourism (Štetić et al., 2013). This tourism industry has $\$ 500$ US billion yearly share in global tourism, indicating the preserved resources' value of \$250 US, through this type of tourism only. In many African and Latin American countries, almost the entire tourism industry is based on the protection of resources. In Yukon, south of Canada, each invested Canadian dollar in a park brings an increase of \$3.50 CAD of income in total (IUCN, 2018).

International Union for the Conservation of Nature (IUCN) describes a protected natural resource as a space that covers protected area of national importance, within which various activities, including tourist ones, are being performed, and it is protected for the reason of preventing exploitation and possible degradation. According to this, the reasons why certain areas or objects are being protected are: their use for the purpose of scientific research, protection of wildlife, preservation of species and genetic diversity, providing services in natural environment, protection of specific natural and cultural forms, tourism and recreation, education, compatible use of resources from natural ecosystems, as well as preserving cultural and traditional characteristics (Mulongoy, Chape, 2004). Modern idea of protected areas dates back from the $19^{\text {th }}$ century with "the novel" Australian, Canadian, New Zealand, South African and USA nation of the time, by declaring Yellowstone as world's first national park, on $1^{\text {st }}$ March 1872 , after which during the $20^{\text {th }}$ century the idea had been spread around the world. The outcome was a significant increase in number of protected areas. Almost every country established laws on protected areas and formed locations for this matter. Abisko was founded in 1909 as the first national park in Europe (Sweden), followed by Engadin in Switzerland, in 1914 (Delić et al., 2017; Vasović, Jovičić, 1984). The oldest known measure of protection for preserving nature was brought in London, in 1273, and it was related to limiting the impact of ash and smoke. In Poland, in 1499, Moose (Alces alces) and Tarpan (Equus caballus gmelini) conservation laws were established, and nature conservation and forestry laws were established in 1597 and in 1769. These laws put certain animal and plant species under their protection. In Middle Ages, first sanctuaries for sacred wildlife in China appeared. In Russia in 1703, some forest complexes with rare tree species were conserved (Vidaković, 1989). Humanity's interest for protection of sites and their visiting throughout the history is best described in the following data: by 2002, about 44,000 locations satisfied the IUCN definition of a protected area, which covered almost $10 \%$ of planet's surface (Eagles-Paul et al., 2002). It is clear that globally protected resources have increased dramatically since the United Nations' first protected properties were released in 1962, with 9,214 protected 
areas on a 2.4 million $\mathrm{km}^{2}$ surface. The number increased from 16,394 in 1972 to 27,794 in 1982. By 1992, there were 43,388 resources, while in the reports from 2003, 102,102 protected locations were displayed, covering an area of 18.8 million $\mathrm{km}^{2}$. This number was equivalent to $12.65 \%$ of land surface, or area which is larger than common surface of China, South and Southeast Asia. Out of this whole protected area, it was estimated that 17.1 million $\mathrm{km}^{2}$ constituted a land surface, which was $11.5 \%$ of the total area in the country. According to the same data source, marine protected areas took up approximately $1.64 \mathrm{~km}^{2}$ of surface in 2003 , and the estimated amount was $0.5 \%$ of the world's sea and less than one tenth of the total surface of protected areas around the world (Hall, Frost, 2009). According to the UN data for the year 2014, there were 209,429 protected areas in a world with a total surface of 32,868,673 $\mathrm{km}^{2}$ - which makes the space larger than the African continent. In total, 3.41\% of the world's marine area and $14 \%$ of the world's terrestrial areas are currently protected. If Antarctica is excluded from the global statistics coverage, the percentage of the total terrestrial area protected is $15.4 \%$. The total area covered with the 10 largest sites (eight of these being marine protected areas) makes more than $20 \%$ of the global area currently protected $\left(32,868,673 \mathrm{~km}^{2}\right)$ (Deguignet et al., 2014). By April 2016, World Database on Protected Areas (WDPA) records 217,155 protected areas appointed from 244 countries and territories included, with 202,467 being terrestrial and 14,688 marine protected areas (UNEP-WCMC, IUCN, 2016). The increase in number of protected resources with specified years can be seen in Figure 1.

Figure 1. Evolution of the terrestrial and marine protected area network, in numbers of sites and areas from 1962. to 2016.

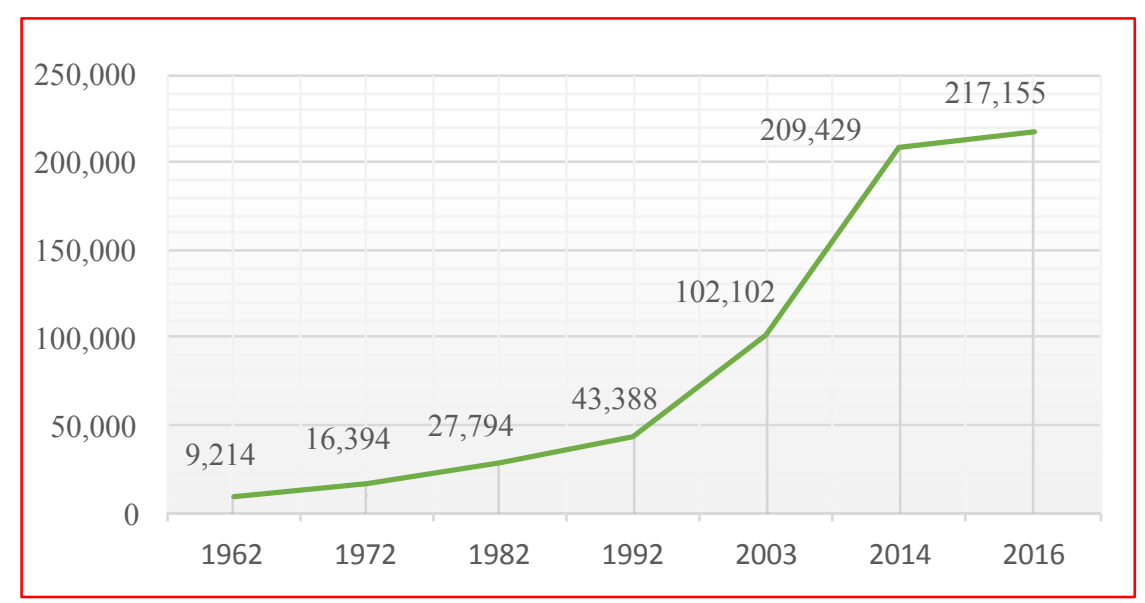

Source: UNEP-WCMC, IUCN, 2016; Trišić, Kostić, 2018.

World Database on Protected Areas recorded 14,688 protected marine areas in 2018, covering 4.12\% (14.9 million $\mathrm{km}^{2}$ ) of global ocean (IUCN, 2018). At the beginning of 2018, there were over 2,200 Ramsar sites that covered more than 2.1 million of 
square kilometers, which was a space larger than Mexico (www.ramsar.org). In 2000 alone, 1,023 aquatic habitats were recorded on the list, covering an area of $749,000 \mathrm{~km}^{2}$ (Eagles, et al., 2001), which was less than half compared to the status from the beginning of 2018. Approximately $65 \%$ of the sites from the protected areas' global network are located in the European region. By contrast, Africa and South America are characterized by relatively small number of protected areas (3.3\% and 1.6\% in total) (Deguignet, et al., 2014). Natural and cultural values on the Man and the Biosphere Programme and World Cultural and Natural Heritage lists are many countries' significant resource of tourist offer. On MAB (Man and the Biosphere Programme) world list there are 669 biosphere reserves in 120 countries, including 20 transboundary sites. Their distribution includes the following: 75 sites in 28 countries in Africa; 31 sites in 11 countries in the Arab States; 147 sites in 24 countries in Asia and the Pacific; 287 sites in 36 countries in Europe and North America, and 129 sites in 21 countries in Latin America and the Carribean (www.unesco.org/new/en/natural-sciences/environment/ecologicalsciences/biosphere-reserves).

The same source indicates that, by 2018, on this list were: Biosphere Mura-DravaDanube Reserve, Danube Delta in Romania, Doñana National Park in Spain, Kiskunság National Park in Hungary, Ichkeul in Tunis, Amboseli in Kenya, Ohrid Prespa, Central Amazon in Brazil, Golija-Studenica, Bačko Podunavlje since 2017, Mount Olympus, the Hawaiian Islands, Julian Alps, Tara River Canyon, The Black Forest (Schwarzwald) since 2017, and many more. The World Cultural and Natural Heritage list registered 830 resources in 2012. 664 from this number were cultural resources, 162 were natural, 24 were mixed, and 34 were singled out as exclusively endangered ones (Holden, 2013); 1, 092 sites were put under protection, 845 of them being cultural, 209 being natural and 38 mixed ones. 54 sites endangered, in total (UNESCO, 2018; http://whc. unesco.org/en/list/). According to the UN definition, National Park is an area of interest for science, education, recreation and tourism. In order for the given area to receive such a status, it needs to have certain surface in its possession, implying a minimum of 2,000 ha, in which: one or more ecosystems exist, undisturbed by human work and presence; in which there are plant and animal species, geomorphological phenomena, settlements of a specific scientific, educational and recreational interest or landscapes of exceptional beauty; in which there are state authorities to prevent exploitation or settling the national park complex, and they work on preserving ecological, geomorphological and esthetic values, for which the national park received its status; and in which visits are allowed, under special terms (for cultural, educational and recreative purposes) (Štetić, Šimičević, 2015).

In the territory of Serbia, different protection measures have been undertaken, in accordance with the adopted European status. In 1839, the first nature conservation act was passed. That was a Decree on the Protection Forest, prohibiting the cutting of "linden mountains". In 1874, on the territory of Serbia, Obed pond received protection status, thus representing the first form of site-based conservation in our country. First National Park Fruska gora was founded on $23^{\text {rd }}$ December, 1960, by adopting the legal 
act in the Parliament of the Republic of Serbia. The reasons for the establishment are: protecting natural beauties, historic monuments, flora and fauna and soil characteristics (Lazić et al., 2008).

By 2016, after establishing the protection regime, Serbia had about 463 natural resources protected on a space covering more than 6.54\% (578,705 ha) of its territory. According to this criterion, it is classified among European countries as a relatively small share of area under the protection of natural heritage, within national territory surface. By 2016, 5 national parks, 71 nature reserves (strict and specialised), 16 nature parks, 42 natural areas around immovable cultural heritage sites, 16 landscapes of exceptional beauty and 313 natural monuments (botanical and dendrological, geomorphological, geological and hydrological ones) were put under protection (Lekić, Jovanović, 2017). Ten areas that enrolled in the list of swamps of international importance had acquired the international protection status - Ramsar sites, with an area of 63,919 ha. These include: Stari BegejCarska Bara, Obedska Bara, Zasavica, Ludaš lake, Slano Kopovo, Gornje Podunavlje, Vlasina, Peštersko polje, Koviljsko-petrovaradinski Rit and Labudovo okno (Delić et al., 2017; http://www.zzps.rs). The same source identified: 42 internationally Important Bird Areas (IBA), 61 internationally Important Plant Areas (IPA) and 40 significant butterfly areas in Europe (Prime Butterfly Areas in Europe - PBA).

The governments of the countries have a large number of possibilities at their disposal, that can prevent negative impact of tourism. On a national, regional and local level, a large set of policies, planned measures and activities preventing bad effects can be implemented. They include the following examples: constituting protected areas by legislation, establishing status of national parks and applying for international recognition of significant sites, such as World Heritage. Furthermore, enforcing planning measures for the site use, by implementing zoning, carrying capacity and using limits of acceptable changes. For certain types of projects, environmental impact analysis is mandatory. Likewise, it is necessary to encourage coordination between government departments in implementing environmental protection policy and engaging in dialogue with the private sector, in order to encourage the adoption of management goal, such as environmental audit and environmental system protection development (Holden, 2008). It is significant to mention that, in the concept of national park management, the management planning goal is to define terms for its arranging and governing, thus increasing possibilities for recreation, protection of park resources and ensuring the public is involved in environmental protection (Jelić, Tomićević-Dubljević, 2015).

The rapid growth of tourism industry in previous years increased the need for more efficient development of tourism management. Tourism generates various effects, both positive and negative, on economy, society and environment around the world. In studying the impact of tourism on environment, a comparative method was used, comparing experiences of foreign tourist destinations. Special attention is paid to integral approach of tourism planning, spatial planning aspects of tourism development and environmental management programs in tourism areas. Despite of tourism playing vital role in many countries' economy, official statistics often fails to provide a 
comprehensive overview of all the benefits and negative impacts. It can be concluded that the tourism industry is very diverse and that various participants are involved in the provision of tourist services and tourism development and management (Trišić, 2012). The interdependence of tourism as a social phenomenon and the environment is inseparable. Under the influence of all social activities and tourism, the environment is changing and modifying, adapting to basic human needs, among which is the tourist need. Each negative environmental change, bearing consequences, is referred to as environmental degradation (Štetić, Trišić, 2018). Given that all natural or cultural resources differ in their time of origin, the extent of value, uniqueness, degree of endangerment and level of damage, IUCN has established categories and types of protected resources. These categories include:

- Category I - Strict Nature Reserve/Wilderness Area: Protected area managed mainly for science or wilderness protection purpose;

o Category Ia - Strict Nature Reserve: Protected area managed mainly for scientific purposes;

o Category Ib - Wilderness Area: Protected area managed mainly for wilderness protection purpose;

- Category II - National Park: Protected area managed mainly for ecosystem protection and recreational purposes;

- Category III - Natural Monument: Protected area managed mainly for conservation of specific natural features;

- Category IV - Habitat/Species Management Area: Protected area managed mainly for conservation through management intervention;

- Category V - Protected Landscape/Seascape: Protected area managed mainly for landscape/seascape conservation and recreation;

- Category VI - Protected Resource Management Area: Protected area managed mainly for the sustainable use of natural ecosystems (Leung et al., 2015).

Tourism and recreation are permitted in all protection areas except in strict nature reserves Ia. Prohibition of using specific parts of nature in tourism is primary, for the sake of site protection. However, these often include the most attractive tourist sites, that can have multiple economic effects on local community. This is one of the biggest issues, since the tourism economy is still not ready to satisfy all protection requirements, and enable tourist movements in protected areas, without bringing destruction and devastation. 'Classic' tourists still haven't developed enough 'ecoconsciousness', that would impact their adequate behaviour in protected sites (Štetić, Šimičević, 2015). 


\section{Zoning}

The purpose of tourism zoning is to use certain territories through equal distribution of tourist capacities, with some territories being exempt from tourist development and others reduced to a certain level, so as to put pressure of tourist traffic or visitors on other less known yet attractive zones (Stamenković, Stojanović, 2009). Tourist movements and individual activities are allowed in every protected natural site, but without implying negative impact on the site and the environment. Some of these sites have more or less sensitive zones, compared to other parts of the same site. In this way, all parts of a protected resource cannot withstand the same pressures. For this reason it is crucial implementing site zoning, which should represent organizational strategy for using specifically protected territories in tourism through even distribution of tourist capacities, in order to preserve natural environment. World Tourism Organization (UNWTO) highlights four important zones in protected natural resources. These include:

- Strict Nature Reserve - in which tourist presence isn't allowed;

- Wildlife Zone - where tourist movement is allowed only by walking;

- Tourist Zone - tourist movement is allowed in several non-degrading ways. Motor vehicles are also allowed, but only the ones using less harmful fuels and producing low pitched noise.

- Managed Resource Zone - where hospitality and tourism facilities are located, with strict control measures, in order to avoid environmental pollution and environmental values being damaged (Stojanović, 2011).

The book "Environment and Tourism" offers an example of zoning carried out by Canadian national park service. This institution established 5 protection zones within protected areas.

- Zone I-Special preservation, includes strictly protected or endangered species, where human access must be strictly controlled;

- Zone II - Wilderness, represents 60 to $90 \%$ of an area inside the territory, within which protection is the primary goal, where services are fairly limited for visitors;

- Zone III - Natural environment, functions as a zone of mitigation between the second and the fourth zone, and the access to this zone is denied for motor vehicles only;

- Zone IV - Outdoor recreation, that includes accommodation services and especially campsites;

- Zone $V$-Park services, covers only $1 \%$ of the park territory and it is significantly modified for the purposes of providing various services for visitors (Holden, 2008). 
The next important analysis deals with the zoning of Great Barrier Reef in Australia, its total length being 2,000 km, representing a habitat of 350 coral species, 1,500 fish and turtle species, as well as many other living world forms. The airports in Townsville and Cairns made possible the arrival of a large number of tourists. The influx of an increasing number of visitors began to endanger this extremely sensitive marine landscape. The marine park management has established four zones:

- Preservation (Pink) Zone, where any type of activities with fatal consequences is excluded;

- Scientific Research (Orange) Zone, in which strictly controlled scientific research is allowed;

- Marine National Park (Green) Zone, in which scientific, educational and recreational activities are allowed;

- General Use (Light Blue) Zone, in which recreational commercial fishing is allowed (Holden, 2008).

The zoning master plan of this area was executed on $1^{\text {st }} \mathrm{July,} 2004$, reducing all previous zoning and protection plans. Great Barrier Reef Marine Park is world's largest protected marine area, after Australian government increased control over the protected area in which fishing and sand mining control had increased from $4.6 \%$ to $33.3 \%$ of protection in total. The area is divided into 70 bioregions, 30 of them being bioregion ridges, and 40 being unregulated bioregions, each with its own rules and regulations. In 2006, a revision was made of the Great Barrier Marine Park Act 1975. Some revision proposals were indicating that there shouldn't exist any changes of zoning plans until 2013, and that every 5 years an Outlook Report should be published, examining the state of Great Barrier Reef, the reef management and environmental state under pressure (Wearing, Neil, 2009).

It is important to analyze an exemplified model of protection on a Greek island Zakynthos in which, by applying different measures, the marine ecosystem and rare sea turtle species (Caretta caretta) are protected. Zakynthos is vital but fragile ecosystem because $80 \%$ of Caretta caretta endangered species that live in the Mediterranean are nesting on the beaches of the Laganas Bay. For this matter, after long-term intensive impact of several conservatory groups, such as MEDASSET, ARCHELON STPS and WWF, Greek government has formed the Presidential Department for establishing National Marine Park on Zakynthos in 1999, in order to protect sea turtles. This park includes three marine zones - A, B, C - in the Laganas Bay, strictly protected nesting zones, and protected terrestrial zones with peripheral zones. Several activities, such as fishing and construction, are limited entirely for the sake of ecosystem protection. Bars, restaurants and other activities aren't allowed on the beaches with nests. There are no pedal boats or canoes for rent, and the number of visitors is controlled by time constraints. The number of beach chairs on Gerakas beach dropped from 180 to 100 . More than $60 \%$ of visitors have become aware of basic steps to avoid impact on sea turtle nests, i.e., the entire beach waste is to be removed including cigarette ends found 
$5 \mathrm{~m}$ away from water (Sigala, 2013; Ryan, 2003). A special tourism framework of preserved parts of nature was provided by Duffus and Dearden. The model contains three components: Species/Habitat, Tourist and Historical Relationship. The model represents a combination of tourism life cycle, leisure specialization continuum and concept of acceptable change. The model of tourism of preserved nature parts implies that in the intial development stage of such destinations, specialized and professional tourists take dominance by meeting their needs in fully respecting and enjoying the wild environment. However, with the increased popularity of certain environmentally protected destinations, the number of non-specialized tourists also increases, and the basis of their satisfaction lies in personal participation and performing activities that are less connected with conserving nature, when they should be, in fact, observing and merging with wild environment.

Zoning in the Republic of Serbia is closely connected with Law on Nature Protection ("Official Gazette of RS", no. 36/2009, 88/2010 and 91/2010 - corr. and 14/2016), according to which the following protected natural resources are defined:

1) Protected landscapes - strict natural reserve, special natural reserve, national park, natural monument, protected habitat, landscape of exceptional characteristics, nature park;

2) Protected species - strictly protected wild species and protected wild species;

3) Mobile protected natural documents.

In protected natural resources of Serbia, zoning is also used through protection regimes. Within their limits, the Ia, Ib, II or III protected area categories are established.

- Ia category - prohibits taking advantage of natural resources and all other forms of the area use and activities, unless they are listed as scientific research and controlled education;

- Ib category - allows exclusively scientific research, controlled education, and activities aimed at preserving and promoting the existing state of ecosystem;

- II category - allows management interventions, for the purpose of restoration and revitalization and overall improvement of the natural resources, without leaving consequences for the primary value of natural habitat, population and ecosystem, as well as controlled traditional values, which during their process, cannot bring damage to primary values of the area;

- III category - allows selected and limited use of natural resources, management interventions for the purpose of restoration, revitalization and overall improvement of the natural resources, sustainable use, development and improvement of rural households, arrangement of cultural and historical heritage facilities, preservation of traditional activities of the local community, infrastructure development intended for tourism development in accordance with sustainable development goals (Law on Nature Protection, 14/2016). 
In its regulations, the Law on Tourism of the Republic of Serbia also deals with the issue of landscape preserving and planning, primarily from the economic and development aspects, especially determining tourist site as a unique and indivisible geographic and functional unity, of natural and created resources, significat for the tourism and its development (Slavković, 2015).

\section{Carrying capacity}

Under the indicators of sustainable tourism development, many authors emphasize carrying capacity as one of the key components of development, with critical points of influence such as: airport, tourist attractions, drinking water supplies, wastewater, protected species, use of protected areas, pollution and emissions of harmful gasses, where special emphasis is put on these destination elements (Holden, 2008).

Estimation of carrying capacity is used as an indicator of tourism impact on environment in tourist sites and regions that represent, at the same time, important planning component of site tourism development. Given that the majority of negative ecological effects and other issues are caused by high density of visitors, tourist capacities and contents, many authors deal with determining the maximum number of tourists that can simultaneously stay in a certain spatial scope. By analyzing available data, a conclusion can be drawn that carrying capacity in global sense represents maximum number of people who can be located in one particular site, without having negative impact on the destination in each aspect of activity. UNWTO defines three levels of estimation of carrying capacity, and these include:

- Environmental capacity - which implies the maximum level of tourist use of the site without causing ecological degradation. Its estimation includes complex consideration of a number of factors such as ecological, geomorphological and climate characteristics, the number of tourists, their activities, construction of tourist facilities, infrastructure, and economic factors.

- Psychological capacity - represents maximum degree of spatial usage, from the aspects of the number of tourists, their activities and built facilities, with decreasing quality of tourist experience.

Table 1. Carrying capacity for tourist destinations and activities according to the European Union standards

\begin{tabular}{|c|c|c|}
\hline \multicolumn{2}{|c|}{ type of recreational area } & suggested capacity per day \\
\hline mountainous area & ski center & 100 skiers per hectare of ski trail \\
\hline \multirow{4}{*}{} & woodland area & up to 15 persons per hectar \\
\cline { 2 - 3 } & park in suburbs & $15-70$ persons per hectar \\
\cline { 2 - 3 } & hiking & 40 persons per kilometer of trail \\
\cline { 2 - 3 } & riding & $25-80$ persons per kilometer of trail \\
\cline { 2 - 3 } & big picnic & $300-600$ persons per hectar \\
\cline { 2 - 3 } & small picnic & $60-200$ persons per hectar \\
\hline
\end{tabular}

Source: Vujović et al., 2012 
This capacity isn't easy to determine given that the perceptions and attitudes of visitors about the aforesaid factors always differ, which is a consequence of wishes, tastes, information and expectations.

- Social capacity - implies the maximum possible tourism development, including the number of tourists, their activities, construction of facilities and infrastructure, which will not harm the lifestyle, culture and tradition of domicile population (Vujović et al., 2012). This capacity can be estimated as the most abstract one, and it is the hardest to estimate (Holden, 2008).

Beside these three listed capacities, some authors also include:

- Economic capacity - representing local economy level of dependence from the degree of tourism development, with the fact that it is not desirable for this dependence to be big.

In certain destinations and in cases when all carrying capacities are positive, a conclusion can be drawn that the final capacity has been achieved. The concept of final (absolute) capacity is one of the basic elements of strategy of sustainable tourism development, through which positive economic, social and ecological results in a destination can be achieved. Absolute carrying capacity of tourist destination consists of spatial, biological, social and psychological aspects of the environment in tourism. One of the most famous uses of absolute capacity concept in tourist literature has been developed by Butler, by modifying life cycle concept, in order to apply it on a tourist destination. According to the theory, the increased number of visitors in a certain area can rapidly result in decreased visits, and the outcome of this is the limit of final (absolute) carrying capacity. It is concluded that the destinations are going through a fairly equal transformation over time, from early research and activation, to consolidation and stagnation, regarding market changes, in order for more visits and competitive destinations to be allowed (Fennell, 2015). A special approach is required at high visitation zones, that put up with the biggest pressure at the same time, and are prone to change ecological balance. In order to estimate the carrying capacity, it is necessary to determine optimal tourist standards, their activities and built facilities, for each tourist site or region individually.

\section{Conclusion}

Tourism research is successful in identifying vast number of social and ecological problems, brought by tourism industry. This dialog is led by different subjects of system protection, and it has become so intensive, that organizations are ready to go even further. This research paper notes meaningful subjects on a global level, and it can be concluded that they have an important, almost unique role in environmental system protection worldwide. Many countries' concern has been invested in site protection models. The aforesaid data draws a conclusion about the ongoing increased number of protected areas, seen as a result of pressure, damage and prevention, humanity's readiness and taking interest in site protection. Through numerous examples, it can be concluded that 
adopting legal acts and status, zoning and carrying capacity are of crucial importance for system protection. All of them have an impact on tourist activities, attractions and consequences of action, in a direct or indirect way. Protected zones put restriction on movements and on the capacity of number of visitors at a certain time interval, whereas legal regulations establish protection and sanction negative influences. The absence of merely one of these system protection models leads to conflicts. Alongside of many tourism impacts on economy, social and natural environment, it is necessary for the sites in which tourist movements occur to be subjected to the process of planning and protection, in order for tourism to be a positive factor in natural and social environment prosperity. Theoretically, the protection of natural resources in the Republic of Serbia is carried out through professional monitoring, determination and directing of measures of active protection, evaluation of phenomena, processes, natural objects and areas, as well as the adoption of appropriate conservation acts. Only future research will show what will be the outcome of these models in terms of preventing negative impacts of tourism on the environmental system protection, and whether this protection is going to be sufficiently implemented, controlled and monitored.

\section{Conflict of interests}

The authors declare no conflict of interest.

\section{Literature}

1. Deguignet M., Juffe-Bignoli D., Harrison J., MacSharry B., Burgess N. D., \& Kingston N. (2014). United Nations List of Protected Areas. UNEP-WCMC, Cambridge, UK.

2. Delić, D., Cvijanović, D., \& Prentović, R. (2017). The Impact of Hunting Tourism on the Protected Areas. University of Kragujevac, Faculty of Hotel Management and Tourism, Vrnjačka Banja. [in Serbian: Делић, Д., Цвијановић, Д., \& Прентовић, Р. (2017), Утицај ловног туризма на заштићена подручја].

3. Duffus, D., \& Dearden, P. A. (2009). Non-consumptive wildlife-oriented recreation: A conceptual framework. Biological Conversation, Vol. 53, 3, 213-231.

4. Eagles-Paul, F. J., McCool, S. F., \& Haynes, C. D. (2002). Sustainable Tourism in Protected Areas, Guidelines for Planning and Management. UNEP \& WTO, Cambridge.

5. Eagles-Paul, F.J., Bowman, M. E., \& Tao, T. C. (2001). Guidelines for Tourism in Parks and Protected Areas of East Asia. IUCN, Cambridge.

6. Fennell, D. A. (2015). Ecotourism, $4^{\text {th }}$ edition. Routledge, Taylor \& Francis Group, London \& New York. ISBN 978-0-415-82965-6 (paperback).

7. Hall, C. M., \& Frost, W. (2009). The making of the national parks concept. In: Tourism and National Parks, International perspectives on development, histories and change; Hall, C. M., Frost, W. (Eds.), 3-15, Routledge, Taylor \& Francis Group, London \& New York. 
8. Holden, A. (2008). Environment and Tourism. Routledge, Taylor \& Francis Group, London \& New York.

9. Holden, A. (2013). Protected Areas and Tourism. In: The Routledge Handbook of Tourism and the Environment; Holden, A. \& Fennell, D. (Eds.) 276-284, Routledge Taylor \& Francis Group, London \& New York.

http://whc.unesco.org/en/list/ (May 29, 2018).

10. IUCN Annual Report for 2017, (2018). IUCN, Gland, Switzerland.

11. Jelić, I., \& Tomićević Dubljević, J. (2015). The Importance of Management Plans in the Management of Protected Areas in Serbia. Sumarstvo, 3, 143-156. [in Serbian: Јелић, И., \& Томићевић Дубљевић J. (2015), Значај планова управљања у управљању заштићеним подручјима Србије].

12. Law on Nature Protection ("Offical Gazette of RS“, no. 36/2009, 88/2010, 91/2010 - corr. and 14/2016). [in Serbian: Закон о заштити природе („Службени Гласник РC“،, 36/2009, 88/2010, 91/2010 - кор., и 14/2016)].

13. Lazić, L., Pavić, D., Stojanović, V., Tomić, P., Romelić, J., Pivac, T., Košić, K., Besermenji, S., \& Kicošev, S. (2008). Protected Natural Resources and Ecotourism in Vojvodina. University of Novi Sad, Faculty of Sciences, Department for Geography, Tourism and Hotel Management. [in Serbian: Лазић, Л., Павић, Д., Стојановић, В., Томић, П., Ромелић, Ј., Пивац, Т., Кошић, К., Бесермењи, С., \& Кицошев, С. (2008), Заштићена природна добра и екотуризам Војводине].

14. Lekić, D., \& Jovanović, M. (Eds.). (2017). The Report on the Environmental Situation in the Republic of Serbia for 2016. Republic of Serbia, Ministry of Environmental Protection, Environmental Protection Agency, Belgrade. [in Serbian: Лекић, Д., \& Јовановић, М. (2017), Извештај о стању животне средине у Републици Србији, 2016].

15. Leung, Y. F., Spenceley, A., Hvenegaard, G., \& Buckley, R. (2015). Tourism and Visitor Management in Protected Areas: Guidelines towards sustainability, Best Practice Protected Area Guidelines Series. IUCN, Gland, Switzerland.

16. Mulongoy, K. J., \& Chape, S. (2004). Protected Areas and Biodiversity, An Overview of Key Issues. United Nations Environment Programme (UNEP), Kenya.

17. Ryan, C. (2003). Recreational Tourism, Demand and Impacts. Channel View Publications, Clevedon.

18. Sigala, M. (2013). Zakynthos: Supply Chain Management and Customers' Involvement in Tourism Sustainability, In: International Cases in Sustainable Travel \& Tourism; Benckendorff, P. \& Lund-Durlacher, 117-134, Goodfellow Publishers, Oxford. 
19. Slavković, V. (2015). Legislation in the Field of Environmental Protection as a Factor of Preserving Tourist Resource Basis. The Business of Tourism, 15, 95-102. [in Serbian: Славковић, В. (2015), Законска регулатива у области заштите животне средине као фактор очувања туристичке ресурсне основе].

20. Stamenković, I., \& Stojanović, V. (2009). Priciples of Sustainable Tourism in the Special Nature Reserve "Titel Hill". Protection of Nature, 60/1-2, 577-592. [in Serbian: Стаменковић, И., \& Стојановић, В. (2009), Принципи одрживог туризма у Специјалном резервату природе „Тителски Брег“].

21. Stojanović, V. (2011). Tourism and Sustainable Development. University of Novi Sad, Faculty of Sciences, Department for Geography, Tourism and Hotel Management. [in Serbian: Стојановић, В. (2011), Туризам и одрживи развој].

22. Stojanović, V., \& Stamenković, I. (2008). Geoturism in the structure of Contemporary Tourist Flow. Bulletin of the Serbian Geographical Society, 88(4), 53-58. [in Serbian: Стојановић, В., \& Стаменковић, И. (2008), Геотуризам у структури савремених туристичких кретања].

23. Štetić, S., \& Šimičević, D. (2015). Tourism Geography. The College of Tourism, Belgrade. [in Serbian: Штетић, С., \& Шимичевић, Д. (2015), Туристичка географија].

24. Štetić, S., \& Trišić, I. (2018). The Impact of Tourism on Water Resources. Conference Environment to Europe, Proceedings EnE18: Nature protection Nature-Responsive Development, 100-105, www.ambassadors-env.com.

25. Štetić, Š., Šimičević, D., \& Ćurčić, N. (2013). Specific Forms of Tourism. Forma B, Belgrade. [in Serbian: Штетић, С., Шимичевић, Д., \& Ћурчић, Н. (2013), Специфични облици туризма].

26. Trišić, I. (2012). The Impact of Tourism on the Mountain and Coastal Areas. Hotel-link, vol. 13, 19-20, 66-80, Belgrade.

27. Trišić, I., \& Kostić, M. (2018). The Importance of Protected Natural Areas for the Development of Tourism Destination. Book of Proceedings, Hotelplan 2018, $7^{\text {th }}$ International Congress, Belgrade, 414-424

28. UNEP-WCMC and IUCN, (2016). Protected Planet Report 2016, UNEPWCMC and IUCN, Cambridge UK and Gland, Switzerland.

29. UNESCO, (2018). World Heritage List. https://whc.unesco.org/en/list/

30. Vasović, M., \& Jovičić, Ž. (1984). More Important Tourism Geographical Regions of Europe, Rad, Belgrade. [in Serbian: Васовић, М., \& Јовичић, Ж. (1984), Важније туристичко географске регије Европе].

31. Vidaković, P. (1989). National Parks and Tourism. Institute for nature conservation, SRH and Instutute for tourism, Zagreb. [in Serbian: Видаковић, П. (1989), Национални паркови и туризам]. 
32. Vujović, S., Cvijanović, D., \& Štetić, S. (2012). Destination Concept of Tourism Development, monograph. Institute of Agricultural Economics, Belgrade. [in Serbian: Вујовић, С., Цвијановић, Д., \& Штетић, С. (2012), Дестинацијски концепт развоја туризма].

33. Wearing, S., \& Neil, J. (2009). Ecotourism: Impacts, Potentials and Possibilities? $2^{\text {nd }}$ edition, Elsevier, Oxford. ISBN 978-0-7506-6249-9

34. www.ramsar.org (March 30, 2018).

35. www.unesco.org/new/en/natural-sciences/environment/ecological-sciences/ biosphere-reserves/ (July 12, 2018).

36. www.zzps.rs (April 10, 2018). 